\title{
STATUS GIZI ANAK BALITA DI WILAYAH KERJA PUSKESMAS HARAPAN RAYA PEKANBARU
}

\section{IKA PUTRI DAMAYANTI \\ STIkes Hang Tuah Pekanbaru}

\begin{abstract}
ABSRTACT
Nutritional status is the level of a person's nutritional status which is stated according to the type and severity of malnutrition. Nutritional status is a result of food instability due to a lack of nutritional value in the consumption of children under five. The nutritional adequacy of children under five is influenced by several factors, which are divided into direct and indirect factors. Direct factors include the level of nutritional consumption, infectious diseases. Meanwhile, indirect factors include family food security, knowledge, attitudes, parenting styles, environmental health, health services, education level, and economic conditions or family income. The purpose of this study was to determine the nutritional status of children under five at Puskesmas Harapan Raya Pekanbaru in 2017.

This type of research is a quantitative analytic study using a cross sectional research design. The population is all children in the work area of Puskesmas Harapan Raya. The sample is some children under five (1-5 years) who are in the working area of the Harapan Raya Community Health Center. Dependent variable is nutritional status, independent variable is knowledge, infection, feeding pattern, utilization of posyandu, family income. This research uses Univariate, Bivariate and Multivariate analysis.
\end{abstract}

Keywords: nutritional status, toddlers, Harapan Raya Community Health Center

\section{INTISARI}

Status gizi adalah tingkat keadaan gizi seseorang yang dinyatakan menurut jenis dan beratnya keadaan kurang gizi. Status gizi merupakan akibat instabilitas pangan karena kurangnya nilai gizi dalam konsumsi balitanya. Kecukupan gizi balita dipengaruhi oleh beberapa faktor yang dibedakan menjadi faktor langsung dan tidak langsung. Faktor langsung meliputi tingkat konsumsi gizi, penyakit infeks. Sedangkan faktor tidak langsung meliputi ketahanan pangan keluarga, pengetahuan, sikap, pola asuh, kesehatan lingkungan, pelayanan kesehatan, tingkat pendidikan, dan kondisi ekonomi atau pendapatan keluarga. Tujuan Penelitian ini adalah untuk mengetahui status gizi anak balita di Puskesmas Harapan Raya Pekanbaru Tahun 2017. 
Jenis penelitian ini adalah penelitian analitik kuantitatif dengan menggunakan desain penelitian cross sectional. Populasi adalah seluruh anak di wilayah kerja Puskesmas Harapan Raya. Sampel adalah sebagian anak balita (1-5 tahun) yang berada di wilayah kerja Puskesmas Harapan Raya. Variabel Dependen adalah status gizi, Variabel Independen adalah Pengetahuan, infeksi, pola pemberian makan, pemanfaatan posyandu, pendapatan keluarga. Penelitian ini menggunakan analisis penelitian Univariat, Bivariat dan Multivariate.

Kata Kunci : Status gizi, Balita, Puskesmas Harapan Raya

\section{PENDAHULUAN}

Status gizi adalah tingkat keadaan gizi seseorang yang dinyatakan menurut jenis dan beratnya keadaan kurang gizi (Arisman, 2004). Kecukupan gizi balita dipengaruhi oleh beberapa faktor yang dibedakan menjadi faktor langsung dan tidak langsung. Faktor langsung meliputi tingkat konsumsi gizi, penyakit infeks. Sedangkan faktor tidak langsung meliputi ketahanan pangan keluarga, pengetahuan, sikap, pola asuh, kesehatan lingkungan, pelayanan kesehatan, tingkat pendidikan, dan kondisi ekonomi atau pendapatan keluarga.

Masalah gizi di Indonesia menggambarkan masalah yang dimulai sejak usia dini kehidupan yaitu pada 1000 Hari Pertama Kehidupan (HPK) dimulai dari 270 hari selama kehamilan dan 730 hari dari kelahiran sampai usia 2 tahun (Pedoman Perencanan Program Gerakan 1000 HPK, 2012). Menurut WHO (World Health Organization), masalah kesehatan masyarakat dianggap serius bila prevalensi status gizi kurang antara 20,0\%-29,0\%. Pada tahun 2013, secara nasional prevalensi gizi buruk dan gizi kurang pada anak balita sebesar 19,6\%, yang berarti masalah gizi buruk san gizi kurang di Indonesia masih merupakan masalah kesehatan masyarakat mendekati prevalensi tinggi.

\section{METODE PENELITIAN}

Jenis penelitian ini adalah penelitian analitik kuantitatif dengan menggunakan desain penelitian cross sectional Populasi dalam penelitian ini adalah seluruh anak balita di wilayah kerja Puskesmas Harapan Raya, Sampel adalah sebagian anak balita (1-5 tahun) yang berada wilayah kerja Harapan Raya..

\section{HASIL PENELITIAN}

Distribusi frekuensi variabel independen pada penelitian status gizi anak balita di wilayah kerja Puskesmas 
Harapan Raya tahun 2017 ditemukan sebagai berikut: Pengetahuan ibu tentang gizi sebagian besar kurang yaitu sebanyak 124 responden $(56,4 \%)$. Pola pemberian makan sebagian besar kurang sebanyak 118 responden $(53,6 \%)$. Pendapatan keluarga sebagian besar kurang sebanyak 116 responden $(52,7 \%)$. Umur ibu sebagian besar muda yaitu sebanyak 133 responden (60,5\%). Pendidikan ibu sebagian besar rendah yaitu sebanyak 118 responden (53,6\%). Pekerjaan orang tua sebagian besar tidak bekerja yaitu sebanyak 147 responden $(66,8 \%)$.

Dari 6 variabel independen ada 4 variabel independen yang berhubungan signifikan dengan status gizi anak balita, yang dijelaskan sebagai berikut:

a. Balita yang memiliki ibu dengan pengetahuan gizi kurang berisiko 10 kali mengalami status gizi kurang dari pada Balita yang memiliki ibu dengan pengetahuan gizi baik dengan POR $10,539(5,620-19,766)$.

b. Balita yang memiliki pola pemberian makanan kurang baik berisiko 7 kali mengalami status gizi kurang dari pada Balita yang memiliki pola pemberian makanan baik dengan POR 7,065(3,899-12,799).

c. Balita yang memiliki pendapatan keluarga kurang berisiko 2 kali mengalami status gizi kurang dari

pada Balita yang memiliki pendapatan keluarga baik dengan POR 2,601 $(1,508-4,485)$.

d. Balita yang memiliki pekerjaan orang tua tidak bekerja berisiko 2 kali mengalami status gizi kurang dari pada Balita yang memiliki orang tua yang bekerja dengan POR 2,397 ( C.I 95\%: $\mathrm{POR}=1,75-6,34)$.

Dari analisis multivariat yang dilakukan : berikut:

a. Ibu yang memiliki pengetahuan kurang berisiko 9 kali untuk mengalami status gizi kurang dibandingkan ibu dengan pengetahuan baik ( C.I 95\%: POR = 4,4-18,4)

b. Ibu yang memiliki pola pemberian makan kurang baik berisiko 8 kali untuk mengalami status gizi kurang dibandingkan ibu dengan pola pemberian makan baik ( C.I 95\%: $\mathrm{POR}=3,8-17,7)$.

Ibu yang memiliki pendapatan keluarga kurang baik berisiko 4 kali untuk mengalami status gizi kurang dibandingkan ibu dengan pendapatan keluarga baik ( C.I 95\%: POR $=2,2-$ $10,6)$ 
PEMBAHASAN

Hubungan Antara Pengetahuan Ibu dengan Status Gizi Anak Balita

Berdasarkan hasil uji regresi logistik, diperoleh Ibu yang memiliki pengetahuan kurang berisiko 9 kali untuk mengalami status gizi kurang dibandingkan ibu dengan pengetahuan baik ( C.I 95\%: POR = 4,4-18,4).

Hasil penelitian ini didukung oleh teori menurut Adriani dan Wirjatmadi (2012), dalam kehidupan sehari-hari sering terlihat orang yang berpenghasilan cukup akan tetapi makanan yang dihidangkan seadanya saja.

Hubungan Antara Pola Pemberian Makan dengan Status Gizi Anak Balita

Berdasarkan hasil uji regresi logistik, diketahui bahwa ibu yang memiliki pola pemberian makan kurang baik berisiko 8 kali untuk mengalami status gizi kurang dibandingkan ibu dengan pola pemberian makan baik ( C.I $95 \%:$ POR $=3,8-17,7)$.

Hasil penelitian in didukung oleh teori menurut Sulistyoningsing (2011), pola makan yang seimbang yaitu sesuai dengan kebutuhan disertai pemilihan bahan makanan yang tepat akan melahirkan status gizi yang baik.
Hubungan Antara Pendapatan Keluarga dengan Status Gizi Anak Balita

Berdasarkan hasil uji regresi logistik, diketahui bahwa ibu yang memiliki pendapatan keluarga kurang baik berisiko 4 kali untuk mengalami status gizi kurang dibandingkan ibu dengan pendapatan keluarga baik ( C.I 95\%: POR = 2,2-10,6).

Hasil penelitian ini didukung oleh teori menurut Adriani dan Wirjatmadi (2012), tingkat pendapatan keluarga yang memadai akan menunjang tumbuh kembang anak, karena orang tua dapat menyediakan semua kebutuhan anak baik primer seperti makan maupun sekunder.

\section{KESIMPULAN}

1. Ibu yang memiliki pengetahuan kurang berisiko 9 kali untuk mengalami status gizi kurang dibandingkan ibu dengan pengetahuan baik ( C.I 95\%: POR = 4,4-18,4)

2. Ibu yang memiliki pola pemberian makan kurang baik berisiko 8 kali untuk mengalami status gizi kurang dibandingkan ibu dengan pola pemberian makan baik ( C.I 95\%: $\mathrm{POR}=3,8-17,7)$.

3. Ibu yang memiliki pendapatan keluarga kurang baik berisiko 4 kali untuk mengalami status gizi kurang 
dibandingkan ibu dengan pendapatan keluarga baik ( C.I 95\%: POR = 2,2$10,6)$.

\section{SARAN}

1. Bagi pihak Puskesmas hendaknya melakukan penyuluhan dan konseling tentang gizi anak balita dan pola pemberian makan yang baik dan seimbang untuk meningkatkan status gizi anak balita, dengan mendatangi setiap posyandu untuk memberi penyuluhan dan meningkatkan peran kader untuk lebih aktif lagi berbaur bersama seluruh warga mengajak untuk mau memanfaatkan fasilitas pelayanan kesehatan atau posyandu dengan semaksimal mungkin

\section{DAFTAR PUSTAKA}

Almatsier, S. (2004).

Prinsip dasar ilmu gizi. Jakarta: Gramedia Pustaka Utama.

Almatsier, S et al. (2011). Gizi seimbang dalam daur hidup. Jakarta: Gramedia Pustaka Utama.

Arisman.(2004). Gizi dalam Daur Kehidupan. Jakarta: EGC.

Badan Penelitian dan Pengembangan Kesehatan Kementerian Kesehatan RI (2010).Riset
Kesehatan Dasar. Jakarta: Departemen Kesehatan RI.

Dahlan. (2010). Besar sampel dan cara pengambilan sampel. Jakarta: Salemba Medika.

Depkes RI. (2006). Pedoman Umum Pengelolaan Posyandu Depkes RI bekerjasama dengan Kelompok Kerja Operasional (POKJANAL POSYANDU): Jakarta

Hidayat, ST dan Jahari, AB. (2012).Perilaku Pemanfaatan Posyandu Hubungannya Dengan Status Gizi dan Morbiditas Balita. Buletin Penelitian Kesehatan Vol 40, No 1 Maret 2012. Diperoleh dari

(http://ejournal.litbang.depkes.go.id /index.php/BPK/article/view/ 2702 diakese pada tanggal 12 Me1 2015) Husin.C.R. (2008).Hubungan pola asuh anak dengan status gizi anak balita umur 24-59 bulan di wilayah kerja terkena tsunami Kabupaten Pidie Provinsi Nanggroe Aceh Darussalam.Medan: Tesis Sekolah Pascasarjana Universitas Sumatra Utara.

Kartasapoetra G dan Marsetyo.(2005). Ilmu gizi (kolerasi gizi, kesehatan dan produksi kerja). Jakarta: Rineka Cipta. 